\title{
HUBUNGAN FAKTOR RISIKO LINGKUNGAN FISIK RUMAH DAN KONTAK PENDERITA DENGAN KEJADIAN PENYAKIT TUBERKULOSIS PARU DI WILAYAH KERJA PUSKESMAS JATILAWANG KABUPATEN BANYUMAS TAHUN 2016
}

\author{
Devi Ratna Yuliani ${ }^{1)}$, M. Choiroel Anwar ${ }^{2)}$, Marsum 3) \\ Jurusan Kesehatan Lingkungan Politeknik Kesehatan Kemenkes Semarang \\ Jl.Raya Baturaden KM 12 Purwokerto, Indonesia
}

\begin{abstract}
Abstrak
Tuberkulosis Paru adalah penyakit menular langsung yang disebabkan oleh kuman TB (Mycobacterium tuberculosis), kuman itu hidup di dalam rumah dan dapat mempengaruhi udara dalam lingkungan fisik rumah. Puskesmas Jatilawang merupakan puskesmas yang memiliki jumlah penderita Tb Paru BTA (+) yang mengalami kenaikan kasus dalam 3 tahun terakhir 21 kasus (2012), 22 kasus (2013) dan 46 kasus (2014). Penelitian ini bersifat observasional dengan menggunakan metode case control. Sampel sebanyak 64 orang, terdiri dari 32 kasus dan 32 kontrol. Variabel yang diteliti meliputi Intensitas pencahayaan rumah,kelembaban,luas ventilasi, jenis lantai, jenis dinding, kepadatan hunian dan kontak penderita. Analisis univariat dan bivariate menggunakan SPSS dengan Uji Chi Square dan OR dengan CI 95\% dan a : 0,05. Analisis Multivariat menggunakan Uji Regresi Logistik dan metode backward; LR CI 95\% dan a:0,25. Hasil penelitian ini adalah Intensitas pencahayaan rumah (intensitas pencahayaan ruang keluarga $(p=0,132 ;$ OR 0,407) dan intensitas pencahayaan ruang kamar $(p=0,024 ; O R$ 0,209)), kelembaban ( $p=1,00 ;$ OR 0,802), luas ventilasi (luas ventilasi ruang keluarga $(p=1,00 ; O R$ 1,00) dan luas ventilasi ruang $\operatorname{kamar}(p=1,00 ;$ OR 1,152)), jenis lantai $(p=1,00 ;$ OR 2,067), jenis dinding $(p=1,00 ;$ OR 1,296), kepadatan hunian $(p=0,606 ;$ OR 3,207) dan kontak penderita $(p=1,00 ;$ OR 1,140). Kesimpulan dari penelitian ini adalah ada hubungan antara intensitas pencahayaan ruang kamar dengan Kejadian Tb Paru. Disarankan untuk penderita Tb Paru membuka jendela kamar dan menambah lubang ventilasi agar cahaya dapat masuk dalam ruang kamar.
\end{abstract}

Kata Kunci $\quad$ : Lingkungan fisik rumah, kontak Penderita, Tb Paru

\begin{abstract}
The Pulmonary Tuberculosis is an infectious disease caused by TB bacteria (Mycobacterium tuberculosis), The bacteria live in the house and can affect the air in the home physical environment. Puskesmas Jatilawang is a puskesmas with the total of patient with Tuberculosis BTA (+) experience a case increase in cases in the last 3 years; 21 cases (2012), 22 cases (2013) and 46 cases (2014). This research is observational using case control method. With total samples of 64 people consist of 32 cases and 32 control. The variable that examined are include the intensity of home lighting, humidity, ventilation, type of floor, type of wall, residential density and patient's contact. Univariate and bivariate analysis using SPSS. SPSS using Chi Square dan OR with CI 95\% and $\alpha: 0,05$. Multivariate analysis using logistic regression and backward method; LR CI 95\% and $\alpha: 0,25$. The result of this research is the intensity of home lighting (the intensity lighting of living room $(p=0,132 ; O R \quad 0,407)$ and the intensity lighting of bed room ( $p=0,024 ;$ OR 0,209)), humidity $(p=1,00 ; O R \quad 0,802)$, ventilation ( the ventilation of the living room $(p=1,00 ; O R 1,00)$ and the ventilation of the bed room $(p=1,00 ; O R 1,152))$, type of floor $(p=1,00 ; O R 2,067)$, type of wall $(p=1,00 ; O R$ 1,296), residential density $(p=0,606 ; O R 3,207)$ and patient's contact $(p=1,00 ; O R 1,140)$. The conclusion of this research is there are relationship between the intensity lighting of the living room with pulmonary Tb. It is suggested that Tb patient must open the room window and increased the number of ventilation so that light can enter into the room.
\end{abstract}

Keywords $\quad:$ Physical Environment Home, patient's contact, Pulmonary Tb

1) E-mail : dratnayuliani@yahoo.com

2)E-mail : Irul1960@yahoo.co.id

3)E-mail : $\underline{\text { marsum178@yahoo.com }}$ 


\section{Pendahuluan}

Tuberkulosis merupakan penyakit menular langsung yang disebabkan oleh kuman TB (Mycobacterium tuberculosis). Sebagian besar kuman TB menyerang paru, tetapi dapat juga mengenai organ tubuh lainnya (Depkes, 2007). Tuberkulosis paru menyebar di udara ketika orang yang sakit mengeluarkan bakteri TB, misalnya dengan batuk. Secara keseluruhan, proporsinya relatif kecil (5-15\%) dari perkiraan 2-3 milyar orang terinfeksi $M$. tuberculosis, bakteri ini akan mengembangkan penyakit TB selama mereka hidup (WHO, 2015).

Indonesia menempati peringkat ke-4 di antara negara-negara TB tertinggi di dunia dan menjadi negara yang memiliki beban tertinggi kasus TB. Estimasi prevalensi semua jenis kasus TB adalah 690.000 dan kejadian di perkirakan adalah 450.000 kasus baru per tahun (WHO, 2011). Perkiraan jumlah akibat kematian TB adalah 64.000 kematian per tahun (WHO,2011).

Berdasarkan Profil Kesehatan Kabupaten Banyumas untuk tahun 2014 tercatat sebanyak 980 kasus baru Tuberkulosis paru dengan BTA (+), Puskesmas Jatilawang merupakan puskesmas yang memiliki kasus Tuberkulosis paru dengan jumlah 46 kasus Tuberkulosis Paru baru dengan BTA (+) di tahun 2014. Kasus pada puskesmas Jatilawang merupakan kasus yang memiliki jumlah yang tinggi dibandingkan tahun sebelumnya yaitu pada tahun 2012 sebanyak 21 kasus dan Tahun 2013 sebanyak 22 kasus baru BTA (+)(Profil Kesehatan Kabupaten Banyumas, 2014). Kasus TB Paru BTA Positif pada tahun 2014 di kecamatan Jatilawang tercatat 13 orang per 100.000 penduduk dengan CDR 20,97\%, berarti di tahun 2014 tidak terjadi penurunan CDR, masih jauh dibawah target IIS 2010 sebesar 70\% (Profil Puskesmas Jatilawang, 2014). Determinan penyakit TB paru adalah kependudukan dan faktor lingkungan. Kependudukan meliputi jenis kelamin, umur, status gizi, kondisi sosial ekonomi. Sedangkan faktor lingkungan meliputi kepadatan, lantai rumah, ventilasi, pencahayaan, kelembaban dan ketinggian (Achmadi, 2008).

Tujuan penelitian adalah untuk mengetahui hubungan faktor risiko lingkungan fisik rumah dan kontak penderita dengan kejadian penyakit tuberkulosis paru di Wilayah Kerja Puskesmas Jatilawang Kabupaten Banyumas tahun 2016.

\section{Bahan dan metode}

Jenis penelitian ini bersifat observasional dengan pendekatan case control, karena pada penelitian bermaksud untuk mencari faktor risiko lingkungan fisik rumah yaitu; Intensitas pencahayaan rumah, Kelembaban, Luas ventilasi, Jenis lantai, Jenis dinding, Kepadatan hunian dan Kontak penderita yaitu; riwayat kontak. Populasi kasus penelitian ini adalah penderita Tuberkulosis Paru BTA (+) di Puskesmas Jatilawang. Populasi kontrol penelitian ini adalah tetangga terdekat penderita Tuberkulosis Paru BTA (+) yang tidak menderita Tuberkulosis Paru BTA
(+) di Puskesmas Jatilawang Kabupaten Banyumas. Jumlah sampel sebanyak 64 orang, terdiri dari 32 sampel kasus dan 32 sampel kontrol. Metode pengumpulan data dilakukan dengan wawancara, observasi dan mengukur langsung intesitas pencahayaan, luas ventilasi dan kepadatan hunian rumah. Analisis data yang digunakan adalah analisis univariat, analisis bivariat menggunakan uji chi square dan odds ratio, analisis multivariat menggunakan uji regresi logistik.

\section{Hasil dan Pembahasan \\ Univariat}

Kontak Penderita

Responden kasus yang mengalami kontak penderita sebanyak 19 orang $(59,4 \%)$ dan yang tidak mengalami kontak penderita 13 orang $(40,6 \%)$. Responden kontrol yang mengalami kontak penderita sebanyak 20 orang $(62,5 \%)$ dan yang tidak mengalami kontak penderita 12 orang $(37,5 \%)$.

\section{Intensitas pencahayaan ruang keluarga}

Rumah responden kelompok kasus yang memiliki intensitas pencahayaan ruang keluarga tidak memenuhi syarat sebanyak 21 rumah $(65,6 \%)$ dan yang memenuhi syarat sebanyak 11 rumah $(34,4 \%)$. Rumah responden kontrol yang memiliki intensitas pencahayaan ruang keluarga tidak memenuhi syarat sebanyak 14 rumah $(43,8 \%)$ dan yang memenuhi syarat sebanyak 18 rumah $(56,3 \%)$.

\section{Intensitas pencahayan ruang kamar}

Rumah responden kasus yang memiliki intensitas pencahayaan ruang kamar tidak memenuhi syarat 28 rumah $(87,5 \%)$ dan yang memenuhi syarat sebanyak 4 rumah (12,5\%). Rumah responden kontol yang memiliki intensitas pencahayaan ruang kamar tidak memenuhi syarat 19 rumah $(59,4 \%)$ dan yang memenuhi syarat sebanyak 13 rumah (40,6\%).

\section{Kelembaban}

Kelembaban rumah pada kelompok kasus yang tidak memenuhi syarat sejumlah 27 rumah $(84,4 \%)$ dan yang memenuhi syarat 5 rumah $(15,6 \%)$. Kelembaban rumah pada kelmpok kontrol yang tidak memenuhi syarat sejumlah 26 rumah $(81,3 \%)$ dan yang memenuhi syarat 6 rumah $(18,8 \%)$.

\section{Luas ventilasi ruang keluarga}

Rumah responden kasus yang memiliki luas ventilasi keluarga tidak memenuhi syarat 13 rumah $(40,6 \%)$ dan memenuhi syarat 19 rumah $(59,4 \%)$. Rumah responden kontrol yang memiliki luas ventilasi keluarga tidak memenuhi syarat 13 rumah $(40,6 \%)$ dan memenuhi syarat 19 rumah $(59,4 \%)$.

\section{Luas ventilasi ruang kamar}

Responden kasus yang memiliki rumah dengan luas ventilasi ruang kamar yang tidak memenuhi syarat 10 rumah $(31,3 \%)$ dan memenuhi syarat 22 rumah $(68,8 \%)$. Responden kontrol yang memiliki rumah dengan luas ventilasi ruang kamar yang tidak memenuhi syarat 11 rumah $(34,4 \%)$ dan memenuhi syarat 21 rumah $(65,6 \%)$. 


\section{Kepadatan hunian rumah}

Rumah responden kasus yang memiliki kepadatan hunian tidak memenuhi syarat sebanyak 1 rumah $(3,1 \%)$ dan yang memenuhi syarat 31 rumah $(96,9 \%)$. Rumah responden kontrol yang memiliki kepadatan hunian tidak memenuhi syarat sebanyak 3 rumah $(9,4 \%)$ dan yang memenuhi syarat 29 rumah $(90,6 \%)$.

\section{Jenis dinding}

Responden kasus yang memiliki rumah yang jenis dindingnya tidak memenuhi syarat 4 rumah $(12,5 \%)$ dan memenuhi syarat 28 rumah $(87,5 \%)$. Responden yang memiliki rumah yang jenis dindingnya tidak memenuhi syarat 5 rumah $(15,6 \%)$ dan memenuhi syarat 27 rumah $(84,4 \%)$.

\section{Jenis lantai}

Rumah responden kasus yang memiliki jenis lantai tidak memenuhi syarat 1 rumah $(3,1 \%)$ dan memenuhi syarat 31 rumah $(96,9 \%)$. Rumah responden kontrol yang memiliki jenis lantai tidak memenuhi syarat 2 rumah $(6,3 \%)$ dan memenuhi syarat 30 rumah $(93,8 \%)$.

\section{Bivariat}

\section{Hubungan Kontak Penderita dengan Kejadian Penyakit TB Paru}

Hasil analisis hubungan antara variabel kontak penderita dengan kejadian TB Paru menggunakan uji chi square menunjukan hasil $\mathrm{p}$ value 1,00 lebih besar dari $\alpha$ : 0,05 maka dinyatakan tidak ada hubungan antara kontak penderita dengan kejadian TB Paru. Pengujian Odds Ratio menunjukan nilai 0,877 yang artinya responden yang mengalami kontak penderita dengan pasien yang terkena TB paru memiliki risiko 0,877 kali lebih besar terkena TB Paru dibandingkan dengan orang yang tidak pernah mengalami kontak penderita dengan pasien TB Paru.

Hasil penelitian ini tidak sama dengan penelitian Dhilah, dkk., (2002) yang menyatakan bahwa adanya interaksi antar anggota keluarga merupakan sarana baik untuk penularan TB, keluarga yang serumah dan terjadi kontak lebih dari satu atau sama dengan 3 bulan berisiko untuk terjadinya TB Paru terutama kontak yang berlebihan melalui berbicara langsung, penelitian yang dilakukan oleh Dhilah, dkk., menunjukan hasil bahwa kontak penderita berisiko terhadap penyakit TB Paru dengan OR sebesar 18,962, dalam penelitian Dhilah, dkk., kontak penderita yang dimaksud kontak penderita yang serumah.

\footnotetext{
Hubungan Intensitas Pencahayaan Ruang Keluarga dengan Kejadian Penyakit TB Paru

Hasil analisis hubungan antara variabel intensitas pencahayaan ruang keluarga dengan kejadian TB Paru menggunakan uji chi square menunjukan hasil $\mathrm{p}$ value 0,132 lebih besar dari $\alpha$ : 0,05 maka dinyatakan tidak ada hubungan antara intensitas pencahayaan ruang keluarga dengan kejadian TB Paru. Pengujian Odds Ratio menunjukan nilai 2,455 yang artinya responden yang memiliki intensitas pencahayaan ruang keluarga yang tidak memenuhi syarat memiliki risiko 2,455 kali lebih besar untuk menderita TB Paru dibandingkan
}

responden yang memiliki intensitas pencahayaan ruang keluarga yang memenuhi syarat.

Penelitian ini tidak sama dengan penelitian Melisah, dkk., (2012) yang menyatakan ada hubungan signifikan antara pencahayaan dengan kejadian penyakit tuberculosis paru, dan di perkirakan risiko pencahayaan yang tidak baik terkena tuberculosis paru 9,33 kali dibandingkan dengan rumah yang memiliki pencahayaan yang baik.

Berdasarkan peneltian yang dilakukan intensitas pencahayaan pada kontrol tidak lebih baik dari pada kasus. Tidak adanya hubungan antara antara variabel pencahayaan dengan kejadian penyakit tuberculosis paru karena hasil yang didapatkan menunjukan bahwa antara responden kasus dan kontrol memiliki intensitas pencahayaan yang tidak jauh beda buruknya.

\section{Hubungan Intensitas Pencahayaan Ruang Kamar dengan Kejadian Penyakit TB Paru}

Hasil analisis hubungan antara variabel intensitas pencahayaan ruang kamar dengan kejadian TB Paru menggunakan uji chi square menunjukan hasil $\mathrm{p}$ value 0,024 lebih kecil dari $\alpha$ :0,05 maka dinyatakan ada hubungan yang signifikan antara intensitas pencahayaan ruang kamar dengan kejadian TB Paru, pengujian odds ratio menunjukan nilai 4,789.

Penelitian ini sama dengan penelitian Hera, dkk., (2012) yang menyatakan bahwa terdapat hubungan antara pencahayaan alami rumah dengan kejadian penyatkit TB paru. Dimana kelompok masyarakat yang memiliki pencahayaan alami rumah <60 lux (tidak memenuhi syarat) kemungkinan menderita penyakit TB Paru sebesar 9 kali dibandingkan kelompok masyarakat yang memiliki pencahayaan alami rumah $\geq 60$ lux (memenuhi syarat).

Berdasarkan penelitian yang dilakukan di Jatilawang hasil pengukuran pencahayaan ruang kamar pada rumah responden kelompok kasus hasilnya sangat sedikit bahkan ada juga yang tidak memiliki jendela atau ventilasi pada ruang kamarnya, ruang kamar pada responden kasus jika tidak diberi penerangan secara buatan, akan memiliki hasil pengukuran yang sangat kecil dan tidak memenuhi syarat.

\section{Hubungan Kelembaban dengan Kejadian Penyakit TB Paru}

Hasil analisis hubungan antara variabel kelembaban dengan kejadian TB Paru menggunakan uji chi square menunjukan hasil $\mathrm{p}$ value 1,00 lebih besar dari $\alpha$ : 0,05 maka dinyatakan tidak ada hubungan antara kelembaban dengan kejadian TB Paru. Pengujian Odds Ratio menunjukan nilai 1,246 yang artinya responden yang memiliki kelembaban rumah yang tidak memenuhi syarat memiliki risiko 1,246 kali lebih besar untuk menderita TB Paru dibandingkan responden yang memiliki kelembaban memenuhi syarat.

Penelitian ini sama dengan penelitian Amalia (2015) yang menyatakan tidak ada hubungan antara kelembaban dengan kejadian penyakit TB Paru 
dengan nilai $\mathrm{p}=0,319$. Jumlah kasus yang tidak memenuhi syarat lebih besar dari kontrol yaitu jumlah responden kasus yang tidak memenuhi syarat ada 27 responden dan jumlah responden kontrol yang tidak memenuhi syarat ada 26 responden, berarti peneliti salah dalam membuat hipotesis, karena hipotesis yang dibuat tidak berdasarkan dengan fakta di lapangan tetapi hanya berdasar pada teori saja. Tidak adanya hubungan kelembaban dengan kejadian penyakit TB Paru karena perbedaan kelembaban antara kasus dan kontrol tidak terlalu jauh berbeda.

\section{Hubungan Luas Ventilasi Ruang Keluarga dengan Kejadian Penyakit TB Paru}

Hasil analisis hubungan antara luas ventilasi ruang keluarga dengan kejadian TB Paru menggunakan uji chi square menunjukan hasil $\mathrm{p}$ value 1,00 lebih besar dari $\alpha$ : 0,05 maka dinyatakan tidak ada hubungan antara luas ventilasi ruang keluarga dengan kejadian TB Paru. Pengujian Odss Ratio menunjukan nilai 1,00 yang artinya responden yang luas ventilasi ruang keluarga tidak memenuhi syarat memiliki risiko 1,00 kali lebih besar untuk menderita TB Paru dibandingkan responden yang memiliki luas ventilasi ruang keluarga yang memenuhi syarat.

Penelitian ini tidak sama dengan penelitian Dwi (2014) yang menunjukan bahwa luas ventilasi ruang terdapat hubungan dengan kejadian tuberculosis paru dengan nilai $\mathrm{p}=0,000<0,05$, faktor risiko luas ventilasi OR 0,038 artinya ada hubungan yang bermakna luas ventilasi rumah terhadap kejadian Tuberkulosis.

Fungsi ventilasi udara adalah untuk menjaga agar aliran udara di dalam rumah tetap segar. Kurangnya ventilasi udara akan menyebabkan kelembaban udara di dalam ruangan naik karena rendahnya cahaya matahari yang masuk dan terjadinya proses penguapan cairan dari penyerapan kulit. Kelembaban ini merupakan media yang baik untuk perkembangan Mycobaterium tuberculosis (Nurhidayah dkk, 2007).

\section{Hubungan Luas Ventilasi Ruang Kamar dengan Kejadian Penyakit TB Paru}

Hasil analisis hubungan antara luas ventilasi ruang kamar dengan kejadian TB Paru menggunakan uji chi square menunjukan hasil $\mathrm{p}$ value 1,00 lebih besar dari $\alpha$ : 0,05 maka dinyatakan tidak ada hubungan antara luas ventilasi ruang kamar dengan kejadian TB Paru. Pengujian Odss Ratio menunjukan nilai 0,868 yang artinya responden yang memiliki luas ventilasi ruang kamar tidak memenuhi syarat memiliki risiko 0,868 kali lebih besar untuk menderita TB Paru dibandingkan responden yang memiliki luas ventilasi ruang kamar yang memenuhi syarat.

Peneltian ini tidak sama dengan penelitian Ryana, dkk., (2012) yang menyatakan bahwa ada hubungan antara luas ventilasi dengan kejadian tuberculosis paru. Sementara hasil perhitungan OR didapatkan 5,2 dengan CI 95\%= 1,7-15,9. Tidak cukupnya ventilasi akan menyebabkan peningkatan kelembaban ruangkan karena terjaidnya proses penguapan cairan dari kulit dan penyerapan.
Penelitian yang dilakukan di wilayah kerja Puskesmas Jatilawang bahwa luas ventilasi tidak ada hubungan dengan kejadian TB Paru, risiko yang dapat terjadi pada responden yang memiliki luas ventilasi ruang kamar yang tidak memenuhi syarat yaitu 0,868 kali lebih besar dibandingkan dengan responden yang memiliki luas ventilasi kamar yang memenuhi syarat. Luas ventilasi kamar cukup penting karena aktifitas manusia minimal 33\% dilaksanakan di kamar yaitu untuk istirahat maka luas ventilasi memiliki peranan penting.

\section{Hubungan Kepadatan Hunian dengan Kejadian Penyakit TB Paru}

Hasil analisis hubungan antara kepadatan hunian rumah dengan kejadian TB Paru menggunakan uji chi square menunjukan hasil $\mathrm{p}$ value 0,606 lebih besar dari $\alpha: 0,05$ maka dinyatakan tidak ada hubungan antara kepadatan hunian rumah dengan kejadian TB Paru. Pengujian Odds Ratio menunjukan hasil 0,312 yang artinya responden yang memiliki kepadatan hunian rumah tidak memenuhi syarat memiliki risiko 0,312 kali lebih besar untuk menderita TB Paru dibandingkan responden yang kepadatan hunian rumahnya memenuhi syarat.

Menurut Juli Soemirat dalam Anggi (2012), kepadatan hunian menentukan insidensi penyakit maupun kematian, terutama di Negara Indonesia yang masih banyak sekali terdapat penyakit menular, seperti penyakit pernapasan dan semua penyakit yang menyebar lewat udara misalnya tuberculosis menjadi mudah sekali menular.

Penelitian ini tidak sama dengan penelitian Dinata (2014), yang menyatakan kepadatan hunian berhubungan dengan kejadian TB Paru dan buku pedoman teknis penilaian rumah sehat untuk sanitarian bahwa faktor risiko lingkungan pada rumah yang dapat mempengaruhi kejadian penyakit TB Paru adalah kepadatan hunian ruang tidur.

\section{Hubungan Jenis Dinding dengan Kejadian Penyakit TB Paru}

Hasil analisis hubungan antara jenis dinding dengan kejadian TB Paru menggunakan uji chi square menunjukan hasil $\mathrm{p}$ value 1,00 lebih besar dari $\alpha: 0,05$ maka dinyatakan tidak ada hubungan antara jenis dinding dengan kejadian TB Paru. Pengujian Odds Ratio menunjukan hasil 0,771 yang artinya responden yang memiliki jenis dinding tidak memenuhi syarat dan tidak kedap air memiliki risiko lebih besar 0,771 kali untuk menderita TB paru dibandingkan dengan responden yang memiliki jenis dinding yang kedap air dan memenuhi syarat.

Penelitian ini tidak sama dengan penelitian Dhilah, dkk., (2012), yang menyatakan bahwa terdapat hubungan yang signifikan antara jenis dinding dengan kejadian TB paru. Risiko kejadian TB Paru dengan dinding yang tidak memenuhi syarat 1,548 kali lebih besar. Dinding rumah yang jarang dibersihkan, banyak mengandung debu dan lembab serta mengandung bakteri merupakan tempat 
berkembang biak bakteri yang baik termasuk Mycobacterium tuberculosis.

Berdasarkan penelitian ini jenis dinding dapat menjadi risiko jika kelembaban dan pencahayaan dalam ruang rumah mendukung akan tumbuhnya bakteri tuberculosis, jadi jika jenis dinding menjadi risiko $\mathrm{Tb}$ paru bisa juga jenis dinding bukan satusatunya faktor yang paling mempengaruhi.

\section{Hubungan Jenis Lantai dengan Kejadian Penyakit TB Paru}

Hasil analisis hubungan antara jenis lantai dengan kejadian TB Paru menggunakan uji chi square menunjukan hasil $\mathrm{p}$ value 1,00 lebih besar dari $\alpha: 0,05$ maka dinyatakan tidak ada hubungan antara jenis lantai dengan kejadian TB Paru. Pengujian Odds Ratio menunjukan hasil 0,484 yang artinya responden yang memiliki jenis lantai tidak kedap air memiliki risiko lebih besar 0,484 kali untuk menderita TB Paru dibandingkan dengan responden yang memiliki jenis lantai yang kedap air dan memenuhi syarat.

Menurut penelitian Dhilah, Nur Nasry dan I Nyoman Sunarka (2012) didapatkan bahwa OR jenis lantai terhadap kejadian TB Paru sebesar 6,217 dengan CI 95\% 2,952-13,095 maka disimpulkan bahwa jenis lantai merupakan faktor risiko kejadian TB paru. Penelitian ini tidak sama dengan penelitian yang dilakukan di wilayah kerja Puskesmas Jatilawang, karena hasil dari penelitian tidak ada hubungan jenis lantai dengan TB Paru. Jenis lantai dapat berpengaruh penting jika kelembaban juga mendukung akan pertumbuhan kuman di lantai, lantai yang terbuat dari tanah atau tidak kedap air berisiko menjadi pertumbuhan kuman tuberkulosis paru.

\section{Multivariat}

Analisis multivariat dilakukan dengan tujuan melihat variabel independen yang paling besar pengaruhnya secara bersama-sama terhadap variabel dependen, diperoleh hasil variabel yang paling berpengaruh yaitu intensitas pencahayaan ruang kamar dengan nilai $\mathrm{p}=0,015$ dan $\mathrm{OR}=4,789$. Artinya bahwa orang yang memiliki intensitas pencahayaan ruang kamar tidak memenuhi syarat memiliki risiko terkena Tuberkulosis Paru 4,789 kali lebih besar dibandingkan dengan orang yang mempunyai intensitas pencahayaan ruang kamar yang memenuhi syarat. Responden yang masih memiliki intensitas pencahayaan < 60 lux terutama pada pencahayaan kamar, seharusnya membuat ventilasi atau jendela yang $>10 \%$ dari luas lantai agar cahaya yang masuk ke dalam ruangan banyak. Cahaya yang masuk dalam ruangan berfungsi sebagai pembunuh bakteri tuberkulosis paru, karena kuman ini akan mati jika terpapar oleh sinar matahari dalam jangka waktu yang lama.

\section{SIMPULAN DAN SARAN}

\section{Simpulan}

1. Deskripsi lingkungan fisik rumah dan kontak penderita dengan kejadian Tuberkulosis Paru di wilayah kerja Puskesmas Jatilawang tahun 2016 : a. Responden yang mengalami kontak penderita pada kelompok kasus sebanyak 19 responden $(59,4 \%)$. Pada kelompok kontrol sebanyak 20 responden $(62,5 \%)$.

b. Responden yang memiliki intensitas pencahayaan ruang keluarga yang tidak memenuhi syarat pada kelompok kasus sebanyak 21 responden $(65,6 \%)$. Pada kelompok kontrol sebanyak 14 responden (43,8\%).

c. Responden yang memiliki intensitas pencahayaan ruang kamar yang tidak memenuhi syarat pada kelompok kasus sebanyak 28 responden $(87,5 \%)$. Pada kelompok kontrol sebanyak 19 responden $(59,4 \%)$.

d. Responden yang memiliki kelembaban tidak memenuhi syarat pada kelompok kasus sebanyak 27 responden $(84,4 \%)$. Pada kelompok kontrol sebanyak 26 responden (81,3\%).

e. Responden yang memiliki luas ventilasi ruang keluarga yang tidak memenuhi syarat pada kelompok kasus sebanyak 13 responden (40,6\%). Pada kelompok kontrol sebanyak 13 responden $(40,6 \%)$.

f. Responden yang memiliki luas ventilasi ruang kamar yang tidak memenuhi syarat pada kelompok kasus sebanyak 10 responden $(31,3 \%)$. Pada kelompok kontrol sebanyak 11 responden $(34,4 \%)$.

g. Responden yang memiliki kepadatan hunian rumah yang tidak memenuhi syarat pada kelompok kasus sebanyak 1 responden (3,1\%). Pada kelompok kontrol sebanyak 3 responden $(9,4 \%)$.

h. Responden yang memiliki jenis dinding tidak memenuhi syarat pada kelompok kasus sebanyak 4 responden $(12,5 \%)$. Pada kelompok kontrol sebanyak 5 responden $(15,6 \%)$.

i. Responden yang memiliki jenis lantai tidak memenuhi syarat pada kelompok kasus sebanyak 1 responden $(3,1 \%)$. Pada kelompok kontrol sebanyak 2 responden $(6,3 \%)$.

2. Analisis hubungan lingkungan fisik rumah dan kontak penderita dengan kejadian Tuberkulosis Paru di wilayah kerja Puskesmas Jatilawang tahun 2016 :

a. Tidak ada hubungan yang bermakna antara Kontak Penderita dengan Kejadian Penyakit Tuberkulosis Paru di Wilayah Kerja Puskesmas Jatilawang Tahun 2016, karena nilai $\mathrm{p}=1,00(\mathrm{p}>0,05)$.

b. Tidak ada hubungan yang bermakna antara Intensitas Pencahayaan Ruang Keluarga dengan Kejadian Penyakit Tuberkulosis Paru di Wilayah Kerja Puskesmas Jatilawang Tahun 2016, karena nilai $\mathrm{p}=0,132(\mathrm{p}>0,05)$. 
c. Ada hubungan yang bermakna antara Intensitas Pencahayaan Ruang Kamar dengan Kejadian Penyakit Tuberkulosis Paru di Wilayah Kerja Puskesmas Jatilawang Tahun 2016, karena nilai $\mathrm{p}=0,024(\mathrm{p}<0,05)$.

d. Tidak ada hubungan yang bermakna antara Kelembaban dengan Kejadian Penyakit Tuberkulosis Paru di Wilayah Kerja Puskesmas Jatilawang Tahun 2016, karena nilai $\mathrm{p}=1,00(\mathrm{p}>0,05)$.

e. Tidak ada hubungan yang bermakna antara Luas Ventilasi Ruang Keluarga dengan Kejadian Penyakit Tuberkulosis Paru di Wilayah Kerja Puskesmas Jatilawang Tahun 2016, karena nilai $\mathrm{p}=1,00(\mathrm{p}>0,05)$.

f. Tidak ada hubungan yang bermakna antara Luas Ventilasi Ruang Kamar dengan Kejadian Penyakit Tuberkulosis Paru di Wilayah Kerja Puskesmas Jatilawang Tahun 2016, karena nilai $\mathrm{p}=1,00(\mathrm{p}>0,05)$.

g. Tidak ada hubungan yang bermakna antara Kepadatan hunian rumah dengan Kejadian Penyakit Tuberkulosis Paru di Wilayah Kerja Puskesmas Jatilawang Tahun 2016, karena nilai $\mathrm{p}=0,606(\mathrm{p}>0,05)$.

h. Tidak ada hubungan yang bermakna antara Jenis Dinding dengan Kejadian Penyakit Tuberkulosis Paru di Wilayah Kerja Puskesmas Jatilawang Tahun 2016, karena nilai $\mathrm{p}=1,00(\mathrm{p}>0,05)$.

i. Tidak ada hubungan yang bermakna antara Jenis Lantai dengan Kejadian Penyakit Tuberkulosis Paru di Wilayah Kerja Puskesmas Jatilawang Tahun 2016, karena nilai $\mathrm{p}=1,00(\mathrm{p}>0,05)$.

3. Faktor yang berisiko

Variabel yang sudah di analisis multivariat menghasilkan variabel yang paling berisiko terhadap kejadian Tuberkulosis Paru di Wilayah Kerja Puskesmas Jatilawang Kabupaten Banyumas Tahun 2016 adalah intensitas pencahayaan ruang $\operatorname{kamar}(\mathrm{p}=0,015)$.

\section{Saran}

1. Bagi Masyarakat

a. Kontak penderita dapat memperbanyak risiko menderita penyakit tuberkulosis paru, oleh karena itu bagi responden yang sakit sebaiknya saat berhadapan dengan orang yang serumah maupun tetangga menggunakan masker sebagai pencegahan dini.

b. Pencahayaan dalam ruang kamar sebaiknya dilakukan dengan membuka jendela kamar dan menambah ventilasi pada ruang kamar agar cahaya dapat masuk dalam ruang kamar.

c. Kelembaban sebaiknya dapat diperbaiki dengan membuka ventilasi rumah yang ditutup rapat dengan kayu sehingga sinar matahari dapat masuk ke dalam rumah.

2. Bagi Dinas Kesehatan Kabupaten Banyumas a. Meningkatkan promosi kesehatan kepada masyarakat tentang syarat-syarat rumah sehat seperti jendela, ventilasi, pencahayaan yang baikdan memberikan informasi tentang syarat rumah sehat yang kurang baik yang ada di masyarakat yang dapat berpengaruh pada kejadian Penyakit Tuberkulosis Paru.

b. Program pemberantasan penyakit sebaiknya tidak hanya melakukan pengobatan terhadap penderita tetapi lebih meningkatkan perbaikan pada lingkungan fisik rumah terutama pada rumah-rumah yang berisiko terhadap kejadian penyakit tuberkulosis paru.

3. Bagi Puskesmas Jatilawang

a. Meningkatkan promosi kesehatan tentang pentingnya rumah sehat berkaitan dengan syarat-syarat rumah sehat dan kontak penderita yang dapat berpengaruh pada jumlah penderia Tuberkulosis Paru.

b. Meningkatkan penyuluhan rumah sehat yang berkaitan dengan penyakit Tuberkulosis paru kepada masyarakat seperti kontak penderita, pencahayaan, luas ventilasi, kepadatan hunian, jenis dinding dan jenis lantai.

\section{Ucapan Terima Kasih}

Terima kasih disampaikan kepada Puskesmas Jatilawang Kabupaten Banyumas, Dinas Kesehatan Kabupaten Banyumas dan Jurusan Kesehatan Lingkungan Politeknik Kesehatan Kemenkes Semarang, sehingga penelitian dapat terselesaikan.

\section{Daftar Pustaka}

Akhsin Zulkoni, 2010, Parasitologi, Yogyakarta : Nuha Medika.

Amalia Kartika Syafri, 2015, Hubungan Kondisi Fisik Rumah dengan Kejadian Tuberkulosis Paru di Wilayah Kerja Puskesmas Ngemplak Boyolali, (online), diunduh pada 17 Juni 21.00 WIB

Anance kotouki, 2012, Gambaran Perilaku Penderita dan Resiko Tuberkulosis BTA Positif dengan Kepatuhan Minum Obat dan Kebiasaan Membuang Dahak di Wilayah Puskesmas Ciomas Kabupaten Bogor Propinsi Jawa Barat, (Online), diunduh pada 20 Januari 21.26 WIB.

Anggie Mareta Rosiana, 2013, Hubungan Kondisi Fisik Rumah dengan Kejadian Tuberkulosis

Paru, (online), (http://journal.unnes.ac.id/sju/index.php/ujph/ article/viewFile/3032/2805), diunduh pada 25 Januari 17.57 WIB.

Aris Santjaka, 2011, Statistik Untuk Penelitian Kesehatan, Yogyakarta : Nuha Medika.

Aru W, dkk., 2010, Buku Ajar Ilmu Penyakit Dalam, Jakarta : InternaPublishing.

Baskoro Iwan Santoso, 2010, Hubungan Kondisi Fisik Rumah dengan Kejadian Penyakit Tuberkulosis di Wilayah Kerja Puskesmas I 
Sokaraja Kabupaten Banyumas Tahun 2010, Purwokerto : Jurusan Kesehatan Lingkungan Purwokerto Poltekkes Kemenkes Semarang.

BIMKMI, 2012, Hubungan Kondisi Fisik Rumah dan Karakteristik Individu dengan Kejadian Tuberkulosis Paru BTA Positif di Puskesmas Ciputat Kota Tangerang Selatan, (online), (http://www.bimkes.org/wpcontent/uploads/downloads/2013/06/BIMKM I\%20Edisi\%201.pdf), diunduh pada 11 Januari 11.21 WIB.

Buchari Lapau, 2009, Prinsip dan Metode Epidemiologi, Jakarta : Balai Penerbit FKUI.

Dhilah Harfadhilah, Nur Nasry Noor dan I Nyoman Sunarka, 2012, Analisa Faktor Risiko Lingkungan Terhadap Kejadian Tuberkulosis Paru, (online), (ojs.uho.ac.id/index.php/medula/article/view /184/127), diunduh pada 17 Juni 21.32 WIB

Djamaluddin Ramlan. 2013, Penulisan Penelitian Eksplanatif. Purwokerto : UPT Percetakan dan Penerbitan Universitas Jenderal Sudirman.

Dwi Ary Murtiningsih, 2014, Pengaruh Ventilasi terhadap Kejadian TB Paru di Wilayah Kerja Puskesmas Sukoharjo Kabupaten Sukoharjo Tahun 2013. (online), (eprints.ums.ac.id/.../11._NASKAH_PUBLIK ASI.pdf), diunduh pada 17 Juni 20.00 WIB.

Dwi Nugraheni, 2011, Analisis Beberapa Faktor yang berhubungan dengan kejadian TB Paru di Kecamatan Karangrayung Kabupaten Grobogan, (online), (http://core.ac.uk/download/files/379/117335 48.pdf), diunduh pada 25 Januari 17.16 WIB.

Fakultas Kesehatan Universitas Indonesia, 2006, Tuberkulosis, Rokok dan Perempuan, Jakarta : FKUI.

Fatah Natsir Gustantyo, 2009, Hubungan Kondisi Rumah terhadap Kejadian TB Paru Anak di Kecamatan Kalibagor Kabupaten Banyumas tahun 2009, Purwokerto : Jurusan Kesehatan Lingkungan Purwokerto Poltekkes Kemenkes Semarang.

Halim Danusantoso, 2000, Buku Saku Ilmu Penyakit Paru, Jakarta : Hipokrates.

Handoko Riwidoko, 2007, Statistik Kesehatan, Yogyakarta : Mitra Cendikia.

Hera T.S Batti, dkk. , 2012, Analisis hubungan antara kondisi ventilasi, kepadatan hunian, kelembaban udara, suhu, dan pencahayaan alami rumah dengan kejadian tuberculosis paru di wilayah kerja puskesmas wara utawa kota palopo, (online), diunduh pada 18 juni 21.00 WIB.

Imam Bachtiar, dkk., 2011, Hubungan Perilaku dan Kondisi Lingkungan Fisik Rumah dengan Kejadian TB Paru di Kota Bima Provinsi $N T B$, (online), diunduh pada 18 juni 22.00 WIB.
Indan Entjang, 2000, Ilmu Kesehatan Masyarakat, Penerbit : PT CITRA ADITYA BAKTI.

Melisah Pitri Siregar, Wirsal Hasan dan Taufik Ashar, 2012, Hubungan Karakteristik Rumah dengan Kejadian Penyakit Tuberkulosis Paru di Puskesmas Simpang Kiri Kota, (online), diunduh pada 16 Juni 19.30 WIB.

Nofianti, 2013, Studi Epidemiologi Kejadian Tuberkulosis Paru di Wilayah Kerja Puskesmas Bobotsari Kabupaten Purbalingga Tahun 2013, Purwokerto : Jurusan Kesehatan Lingkungan Purwokerto Poltekkes Kemenkes Semarang.

Nur Nasry Noor, 2008, Epidemiologi, Jakarta : PT RINEKA CIPTA.

Rusnoto, Pasihan Rahmatullah dan Ari Udiono, 2008, Faktor-faktor Yang Berhubungan dengan Kejadian TB Paru Pada Usia Dewasa (Studi Kasus di Balai Pencegahan dan Pengobatan Penyakit Paru Pati), (online), (http://core.ac.uk/download/pdf/11706079.pd f), diunduh pada 21 Januari 21.51 WIB.

Ryana Ayu Setia Kurniasari, dkk., 2012, Faktor Risiko Kejadian Tuberkulosis Paru di Kecamatan Baturetno Kabupaten Wonogiri, (online), diunduh pada 18 Juni 21.15 WIB.

Soekidjo Notoatmodjo, 1997, Ilmu Kesehatan Masyarakat Prinsip-prinsip Dasar, Jakarta : PT RINEKA CIPTA.

Sri Soewasti Soesanto, Augustina Lubis dan Kusnindar Atmosukarto, 2000, Hubungan Kondisi Perumahan dengan Penularan Penyakit ISPA dan TB Paru, (online), (http://ejournal.litbang.depkes.go.id/index.ph p/MPK/article/viewFile/979/791), diunduh pada 24 Februari 20.30 WIB.

Suharmadi, 1985, Perumahan Sehat, Bandung : Proyek Pengembangan Pendidikan Tenaga Sanitasi Pusat.

Suyono dan Budiman, 2012, Ilmu Kesehatan Masyarakat Dalam Konteks Kesehatan Lingkungan, Jakarta : Buku Kedokteran EGC.

Thabrani Rab, 2010, Ilmu Penyakit Paru. Jakarta : Trans Info Media.

Timmreck dan Thomas C, 2005, Epidemiologi Suatu Pengantar Edisi 2, Jakarta : buku Kedokteran EGC.

Tri Cahyono, 2014, Pedoman Penulisan Proposal Penelitian dan Karya Tulis Ilmiah/ Skripsi (Edisi Revisi Ketiga), Purwokerto : Jurusan Kesehatan Lingkungan Purwokerto Poltekkes Kemenkes Semarang.

Tuti Susilowati, 2010, Faktor-faktor yang berpengaruh terhadap Kejadian Tuberculosis di Kecamatan Kaliangkrik Magelang (Studi tentang kontak langsung dengan pasien BTA Positif Tuberculosis), (online), (http://ejournal.akbidpurworejo.ac.id/index.php/jkk3/article/view/5 6), diunduh pada 21 Januari 10.21 WIB. 
Umar Fahmi A, 2008, Manajemen Penyakit Berbasis Wilayah, Jakarta : UI-Press.

WHO, 2015, Global Tuberculosis Report 2015. (online).

.(http://apps.who.int/iris/bitstream/10665/191 102/1/9789241565059_eng.pdf?ua=1), diunduh pada 15 Desember 23.48 WIB.
Widoyono, 2008, Penyakit Tropis Epidemiologi, Penularan, Pencegahan Pemberantasannya, Jakarta : Erlangga.

Yuyun Ayunah, 2008, Hubungan antara faktor-faktor kualitas lingkungan fisik rumah dengan kejadian TB Paru BTA Positif di Kecamatan Cilandak Kotamadya Jakarta Selatan, (online), http://lib.ui.ac.id, diunduh pada 26 Januari 9.17 WIB. 